\title{
Production of Dimethyl Sulfide from Unicellular Algae
}

\author{
Yūzaburõ IsHIDA* and Hajime KADOTA* \\ (Received May 2, 1967)
}

It is well known that some multicellular marine algae, such as Polysiphonia lano$s a^{11}$, Polysiphonia fastigiata ${ }^{2,31}$, Enteromorpha intestinali ${ }^{4,51}$, and Ulva pertusa ${ }^{5,61}$ evolve volatile sulfur compounds which have "iso-no-kaori", a unique smell of the sea. In some cases the main component of these volatile compounds was reported to be dimethyl sulfide ${ }^{2,3)}$. According to Motohiro ${ }^{71}$, Ronald and Thomson ${ }^{8)}$, Sipos and Ackman ${ }^{91}$, and Ackman et al. ${ }^{10,11}$, the smell of some marine fishes and mollusks may also be attributable to dimethyl sulfide and its related compounds which were brought into the animals through their food algae. Recently Ackman et al. ${ }^{11}$ and Tocher $e t$ $a l .{ }^{12)}$ have demonstrated that dimethyl sulfide was evolved by alkali treatment from several species of the unicellular algae of marine origin. These reports suggest that the evolution of dimethyl sulfide is characteristic of marine organisms, especially of marine algae.

The present work was made to gain a more detailed understanding of the biological significance of the production of volatile sulfur compounds, especially dimethyl sulfide from unicellular algae, and mainly concerned with the fractionation and identification of volatile sulfur compounds which were evolved from these organisms during their growth.

\section{Materials and Methods}

Organisms. Bacteria-free unicellular algae used in this work were Gyrodinium cohnii (heterotrophic) ${ }^{13 * *}$, Amphidinium carterii (photoautotrophic)14)**, Glenodinium sp. (photoautotrophic) ${ }^{14 * *}$, Nanochloris oculata (photoautotrophic) ${ }^{15 \% * * *}$, Chlamydomonas sp. (photoautotrophic, isolated by us) ${ }^{16)}$, Haematococcus pluvialis (heterotrophic) ${ }^{17) * *}$, Polytoma uvella (heterotrophic) ${ }^{18)}$, Chlamydomonas komma (photoautotrophic) ${ }^{19) * * * *}$, Scendesmus obliquus (photoautotrophic) ${ }^{19) * * * *}$, Chlorella vulgaris (photoautotrophic) $\left.{ }^{19}\right)^{* * * *}$, Chlorella pyrenoidosa (photoautotrophic) ${ }^{19) * * * *}$, Euglena gracilis (photoautotrophic) ${ }^{19) * * * *}$, and Astasia longa (heterotrophic) ${ }^{201 * * * *}$. Of these the first mentioned five species were of marine origin and the other strains were isolated from fresh-water environments.

Culture media and culture conditions. The algae tested were cultivated by use of chemically defined media which were prepared according to the respective refer-

* Research Institute for Food Seience, Kyoto University, Kyoto, Japan. (京都大学食糧科学研究 所)

** Provided by Dr. L. Provasoli.

*** Provided by Dr. M. Droop.

**** Provided by Dr. Y. Tubo. 
ences. The kind and concentration of sulfur sources in the media, however, were somewhat modified from those reported originally; as the source of sulfur, $20 \mathrm{mg}$ $\mathrm{Na}_{2} \mathrm{SO}_{4}$ and $0.2 \mathrm{mc} \mathrm{H}_{2}{ }^{85} \mathrm{SO}_{4}$ were supplemented to $100 \mathrm{~m} l$ media in all the cases. In the case of photoautotrophs, cultures were kept at $20^{\circ} \mathrm{C}$ under illumination of fluorescent lights $(4,000$ lux $)$.

Determination of volatile sulfur compounds. Dimethyl sulfide and the other volatile sulfur compounds evolved from the cultures or the cells were chromatographically identified by use of a Yanagimoto Model GCG-2 gas chromatography apparatus with the hydrogen flame ionization detector. As the column, a $0.005 \times 2.0 \mathrm{~m}$ brass tubing containing firebricks impregnated with didecylphthalate ${ }^{21)}$ or Apiezon $\mathrm{M}^{22}$ was used. Radioactivity of the volatile sulfur compounds labeled with ${ }^{35} \mathrm{~S}$ was determined using an anthracene-flow cell (FC-11), connected with the gas chromatography apparatus, or a Packard Tri-Carb liquid scintillation spectrometer Model 314.

\section{Results and Discussion}

Composition of volatile sulfur compounds evolved from various unicellular algae during the growth. Volatile sulfur compounds evolved from several representative species of marine and fresh-water unicellular algae during cultivation were fractionated, by use of the absorption train system illustrated in Fig. 1, to three different

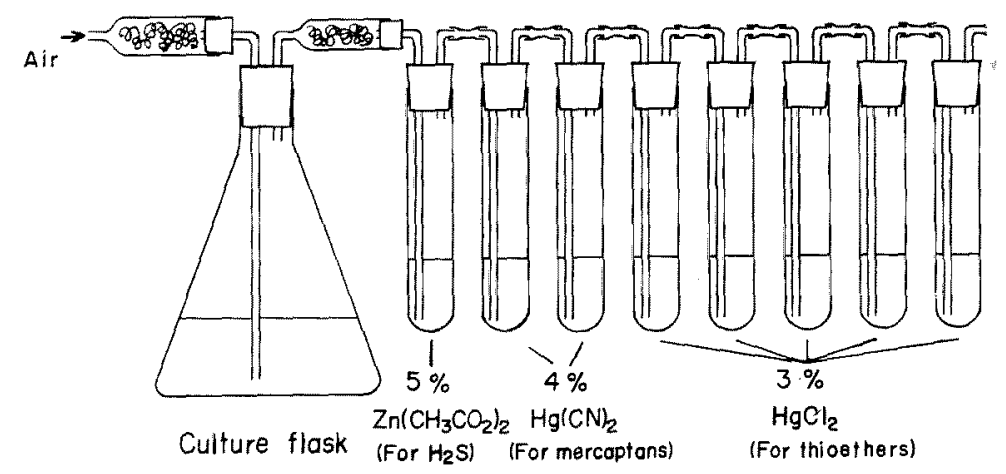

Fig. 1. Absorption train for determining the volatile sulfur compounds evolved from algal cultures.

parts; thioether fraction, mercaptan fraction and $\mathrm{H}_{2} \mathrm{~S}$ fraction. Radioactivities of these fractions were respectively determined by using the liquid scintillation counter.

The results obtained are shown in Table 1 and indicate that the composition of volatile sulfur compounds evolved during cultivation was fairly different with the species. The greater part of the organisms examined, i. e., Amphidinium carterii, Glenodinium sp., Chlamydomonas sp., Nanochloris oculata, Haematococcus pluvialis, Polytoma uvella, Chlamydomonas komma, Scenedesmus obliquus, Chlorella vulgaris and Chlorella pyrenoidosa produced $\mathrm{H}_{2} \mathrm{~S}$ as the major product. The algae belonging to 
Table 1. Evolution of thioether, mercaptan and $\mathrm{H}_{2} \mathrm{~S}$ from various marine and fresh-water algae during cultivation ( 4 days' incubation).

\begin{tabular}{|c|c|c|c|c|c|c|}
\hline \multirow[b]{2}{*}{ Organisms } & \multicolumn{2}{|c|}{ Thioether $-{ }^{-35} \mathrm{~S}$} & \multicolumn{2}{|c|}{ Mercaptan- ${ }^{-35} \mathrm{~S}$} & \multicolumn{2}{|c|}{$\mathrm{H}_{2} \mathrm{~S}-85 \mathrm{~S}$} \\
\hline & $\begin{array}{c}\text { Evolved } \\
\text { from } 200 \mathrm{ml} \\
\text { culture } \\
\text { (cpm) } \\
\end{array}$ & $\begin{array}{c}\% \text { of } \\
\text { total as } 5 \\
\text { evolved }\end{array}$ & $\begin{array}{c}\text { Evolved } \\
\text { from } 200 \mathrm{ml} \\
\text { culture } \\
\text { (cpm) }\end{array}$ & $\begin{array}{l}\% \text { of } \\
\text { total } 85 \mathrm{~S} \\
\text { evolved }\end{array}$ & $\begin{array}{c}\text { Evolved } \\
\text { from } 200 \mathrm{ml} \\
\text { culture } \\
\text { (cpm) }\end{array}$ & $\begin{array}{l}\% \text { of } \\
\text { total }{ }^{35} \mathrm{~S} \\
\text { evolved }\end{array}$ \\
\hline \multicolumn{7}{|l|}{ Marine algae: } \\
\hline Gyrodinium cohnii & 72,300 & 65.3 & 27,600 & 24.9 & 10,800 & 9.8 \\
\hline Amphidinium carterii & 3,500 & 2.1 & 1,100 & 0.7 & 167,300 & 97.2 \\
\hline Glenodinium sp. & 630 & 3.7 & 150 & 0.9 & 16,000 & 95.4 \\
\hline \multirow[t]{2}{*}{ Chlamydomonas sp. } & 1,700 & 9.3 & 3,800 & 20.5 & 12,900 & 70.2 \\
\hline & 300 & 2.2 & 700 & 5.4 & 12,000 & 92.4 \\
\hline \multicolumn{7}{|l|}{ Fresh-water algae: } \\
\hline Haematococcus pluvialis & 400 & 7.0 & 1,500 & 25.6 & 3,900 & 67.5 \\
\hline Polytoma uvella & 250 & 0.2 & 5,400 & 2.8 & 181,100 & 97.0 \\
\hline Chlamydomonas komma & 600 & 3.6 & 5,500 & 32.4 & 10,900 & 64.0 \\
\hline Scenedesmus obliquus & 600 & 4.3 & 3,700 & 25.1 & 10,500 & 70.6 \\
\hline Chlorella vulgaris & 2,400 & 3.6 & 11,400 & 17.1 & 53,200 & 79.4 \\
\hline Chlorella pyrenoidosa & 1,000 & 3.2 & 7,600 & 24.2 & 22,800 & 72.6 \\
\hline Astasia longa & & & & & & \\
\hline (chem. def. med.) & 600 & 18.2 & 1,900 & 57.6 & 800 & 24,2 \\
\hline (BPYA med.) & 100 & 11.1 & 400 & 44.5 & 400 & 44.5 \\
\hline \multicolumn{7}{|l|}{ Euglena gracilis $Z$} \\
\hline (light, $\mathrm{pH} 3.3$ ) & 4,800 & 4.9 & 79,600 & 81.4 & 13,300 & 13.7 \\
\hline (dark, $\mathrm{pH} 7.2$ ) & 700 & 8.9 & 5,600 & 76.4 & 1,100 & 14.8 \\
\hline
\end{tabular}

Euglenales, e. g., Astasia longa and Euglena gracilis produced mercaptan in the largest amount. The organism which produced thioether as the major product was Gyrodinium cohnii; in case of this organism more than $60 \%$ of the sulfur evolved was thioether. Among the algae used in this experiment Gyrodinium cohnii was the only heterotroph which was isolated from the sea. It is, therefore, suggested that the vigorous production of thioether during the growth may be a characteristic of heterotrophic algae of marine origin.

Production of thioether from algal cells by alkali treatment. To ascertain whether some precursor(s) of thioether is (are) present in the algal cells or not the amount of thioether which was evolved from the ${ }^{35} \mathrm{~S}$-labeled cells of various algae by cold alkali treatment was determined using radioisotope methods.

The results are given in Table 2 , and indicate that a large amount of thioether was evolved from the cells of Gyrodinium cohnii and Amphidinium carterii, both belonging to marine dinoflagellates. Of these algae the latter one did not produce thioether as a natural metabolic product during the growth, as shown in Table 1. This alga, therefore, was proved to possess, in the cells, some precursor ( $\mathrm{s}$ ) of thioether, from which thioether was not evolved under the natural condition. 
Table 2. Evolution of thioether from various algal cells treated with cold alkali ( 2 hours' treatment)

\begin{tabular}{l|c}
\hline \multicolumn{1}{c|}{ Organisms } & $\begin{array}{c}\text { Thioether-35S per total } \\
\text { 85S from the cells } \\
\left(\times 10^{-3}\right)\end{array}$ \\
\hline Marine algae: & \\
Gyrodinium cohnii & 68.0 \\
Amphidinium carterii & 75.0 \\
Glenoidinium sp. & 0.6 \\
Chlamydomonas sp. & 0.5 \\
Nanochloris oculata & 1.4 \\
Fresh-water algae: & \\
Chlamydomonas komma & $0.1>$ \\
Scenedesmus obliquus & $0.1>$ \\
Chlorella vulgaris & $0.1>$ \\
Chlorella pyrenoidosa & $0.1>$ \\
Euglena gracilis $Z$. & \\
(light, pH 3.3) & 0 \\
(dark, pH 7.2$)$ & $0.3>$ \\
\hline
\end{tabular}

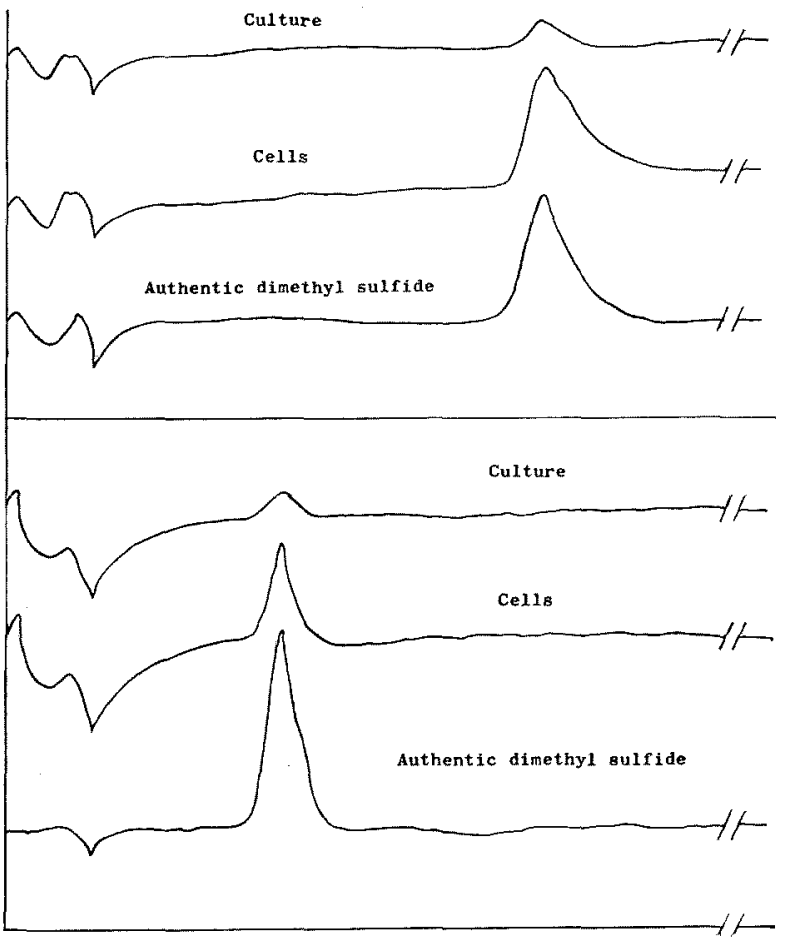

Fig. 2. Gas chromatographic analysis of the thioether fractions obtained from Gyrodinium cohnii. Didecylphthalate column was used for the upper curves, and Apiezon $\mathrm{M}$ column for the lower curves.
Identification of dimethyl sulfide evolved from Gyrodinium cohnii. Volatile sulfur compounds evolved from Gyrodinium cohnii were separated and identified by gas chromatographic techniques. The gas chromatographic patterns obtained with the culture and the cells treated with alkali are shown in Fig. 2. In this figure the pattern of authentic dimethyl sulfide is also shown for comparison's sake.

This result indicates that the thioether fractions obtained from both the culture and the alkalitreated cells mainly consisted of dimethyl sulfide.

In order to confirm the above-mentioned findings the thioether fraction obtained from the cells of Gyrodinium cohnii which were harvested from the culture labeled with ${ }^{35} \mathrm{~S}$ was further examined by use of an anthracene flow cell connected with the gas chromatographic apparatus. As illustrated in Fig. 3, the radioactive peak detected by flow detector exactly corresponded to the peak in the gas chromatographic pattern.

From these data it was confirmed that the thioether fraction obtained from Gyrodinium cohnii was principally composed of dimethyl sulfide. 


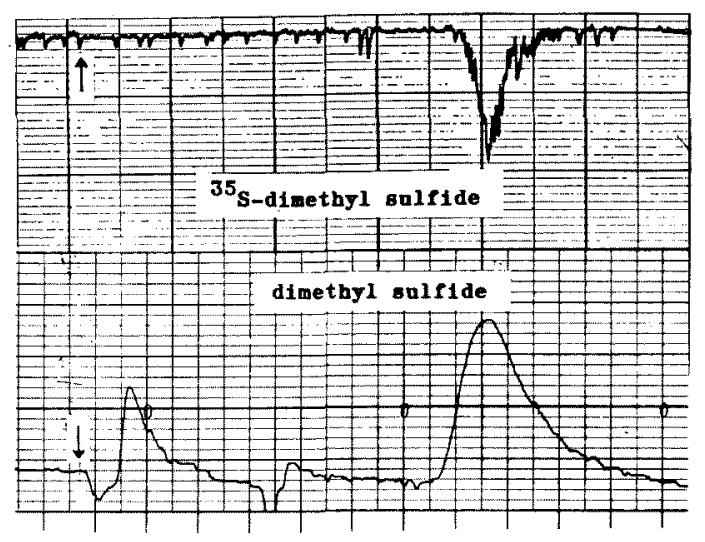

Fig. 3. Gas chromatographic (lower) and radiogas chromatographic (upper) patterns of the thioether fraction obtained from the ${ }^{35} \mathrm{~S}$ labeled cells of Gyrodinium cohnii.

Gas chromatograph: Yanagimoto model GCG-2 with thermister detector.

Column: $0.005 \times 2 \mathrm{~m}$ brass tube containing $60 \sim 80$ mesh firebrick coated with $30 \%$ Apiezon M. Anthracene-flow cell (FC-11) was connected with the gas chromatograph.
In the case of Amphidinium carterii, the principal component of the thioether fraction obtained from the alkali-treated cells was also found to be dimethyl sulfide.

It was also suggested from these experiments that the ability to produce thioether, mercaptan or $\mathrm{H}_{2} \mathrm{~S}$ might be related to the metabolic type, and/or the culture conditions of the algae.

\section{Summary}

Volatile sulfur compounds evolved from various unicellular algae during cultivation were fractionated to three different parts: thioether fraction, mercaptan fraction and $\mathrm{H}_{2} \mathrm{~S}$ fraction. Major component of the volatile sulfur compounds produced from Amphidinium carterii, Glenodinium sp., Chlamydomonas sp., Nanochloris oculata, Haematococcus pluvialis, Polytoma uvella, Chlamydomonas komma, Scenedesmus obliquus, Chlorella vulgaris and Chlorella pyrenoidosa was $\mathrm{H}_{2} \mathrm{~S}$, and that from Astasia longa and Euglena gracilis was mercaptan. Gyrodinium cohnii, a heterotrophic dinoflagellate of marine origin evolved thioether as the major product.

The thioether fraction obtained from Gyrodinium cohnii, was found by gas chromatographic analysis to be principally composed of dimethyl sulfide.

These data suggested that the ability of unicellular algae to produce thioether, mercaptan or $\mathrm{H}_{2} \mathrm{~S}$ was related to some extent to the metabolic type or the environmental factors of natural habitats of the organism.

This work was supported in part by research grant from the Ministry of Education, Japan.

\section{References}

1) G. L. Cantoni and D. G. Anderson: J. Biol. Chem., 222, 171 177 (1956).

2) F. Challenger and M. I. Simpson: J. Chem. Soc., 1948, $1591 \sim 1597$.

3) P. HAAS: Biochem. J., 29, 1297 (1935).

4) R. BYwood and F. Chaldenger: ibid., 53, XXVI (1953).

5) Y. Obata, H. Igarashi and K. Matano: This Bull., 17, 60 62 (1951).

6) T. Katayama and T. Tomiyama: This Bull., 17, 122 127 (1951).

7) T. Мотоніво: Mem. Fac. Fish., Hokkaido Univ., 10, 1 65 (1962). 
8) A. P. Ronald and W. A. B. Thomson: J. Fish. Res. Bd. Canada, 21, $1481 \sim 1487$ (1964).

9) J. C. Sipos and R. G. ACKMAN: ibid., 21, $423 \sim 425$ (1964).

10) R. G. Ackman, C. S. Tocher and J. MClachlan, ibid. 23, $357 \sim 364$ (1966).

11 R. G. ACKMAN, J. DALE and J. Hingley: ibid., 23, 487 497 (1966).

12) C.S. Tocher and R. G. AckMAN: Can. J. Biochem., 44, 519 522 (1966).

13) Y. Ishida and H. Kadota: Mem. Res. Inst. Food Sci., Kyoto Univ., 26, $10 \sim 17$ (1965).

14) L. Provasoli: Proc. 4th Intern. Seaweed Sym., 9 17 (1963).

15) J. Ryther: N. Y. Biol. Bull., Woods Hole, 106, 198 209 (1954).

16) Y. ISHIDA and H. KADOTA: unpublished.

17) T. W. GOODWIN and M. JAMIKORN: Biochem. J., 57, 376 380 (1954).

18) V.P. Cirillo: J. Protozool., 3, 69 74 (1956).

19) A. Watanabe: J. Gen. Appl. Mierobiol., 6, 283 292 (1960).

20) G. M. Padilla and T. W. James: Exptl. Cell Res., 20, $401 \sim 415$ (1960).

21) M. R. Gumbmann and H. K. BurR: J. Agr. Food Chem., 12, 404 408 (1964).

22) F. BAUMANN and S. A. OLUND: J. Chromatog., 9, $431 \sim 438$ (1962). 